\title{
SAUDAÇÃO PROFERIDA PELO PROFESSOR EROS ROBERTO GRAU AO NOVO TITULAR, PROFESSOR PAULO DE BARROS CARVALHO
}

Excelentíssima Senhora Diretora, D. Congregação, minhas Senhoras, meus Senhores, meu caro amigo professor Paulo de Barros Carvalho:

Aqui estamos reunidos para celebrar a posse do professor doutor Paulo de Barros Carvalho no cargo de professor titular da Faculdade de Direito do Largo de São Francisco.

Esta, entre tantas belas tradições da Faculdade de Direito do Largo de São Francisco, é uma das suas mais belas tradições. Celebramos a admissão definitiva do professor doutor Paulo de Barros Carvalho na velha e sempre nova Academia.

Desde agora poderá, o professor, fruir daquela que já uma vez afirmei, perante essa D. Congregação, ser uma das mais enternecedoras sensações - a sensação que nos toma quando, ao passarmos pelas Arcadas, nos dizemos a nós mesmos, em silêncio: "esta é a minha casa, a velha e sempre nova Academia; aqui, aonde mora a amizade e se constrói a liberdade" E dizemos isso, a nós mesmos, pisando o chão do pátio das Arcadas transformado no jardim cantado por Goffredo, pleno de flores.

Que bom, repito-o, que bom podermos dizer - fingindo humildade que bom podermos dizer, singelamente, se alguém pergunta o que fazemos, que bom podermos dizer, simplesmente: "sou professor no Largo de São Francisco!"

Aqui estamos, agora, para celebrar a admissão definitiva do professor doutor Paulo de Barros Carvalho na velha e sempre nova Academia.

Bacharel em Direito em 1965, em 1969 tornou-se especialista em Direito Comercial, em nosso antigo curso de especialização.

Após, em 1973 Doutor e, em 1981, Livre-Docente, em Direito Tributário pela PUC-SP, Faculdade de Direito na qual alcançou a titularidade em Direito Tributário em 1985. Daí as teses " $A$ estrutura lógica da norma juridica, tributária" "A regra-matriz do ICM" e "Questões substanciais de Direito Tributário"

E a tanto se acrescente, entre outros mais, os livros "Teoria da norma tributária", "A inconstitucionalidade dos tributos fixos", "Decadência e prescrição no Direito Tributário" e "Curso de Direito Tributário" — este já em décima edição. 
Mais recentemente, a tese apresentada ao concurso para professor titular das Arcadas — "Fundamentos jurídicos da incidência"

A produção intelectual do professor Paulo de Barros Carvalho é amplíssima, compreendendo ainda, além de outros livros, inúmeros artigos e pareceres.

Toda sua carreira acadêmica foi feita mediante concursos públicos e, sem nenhuma dúvida, no seu desempenho o professor a honrou.

Em 1987 fundou a cadeira de Lógica Jurídica no curso de Mestrado da Faculdade de Direito da PUC, lecionando a matéria até hoje. É bem sabido, de resto, que Paulo de Barros Carvalho vem sistematicamente empreendendo pesquisas no campo da Teoria Geral do Direito e da Filosofia do Direito visando imprimir maior profundidade às especulações à propósito do Direito Tributário.

A atividade de Paulo de Barros Carvalho na Universidade é também extremamente relevante. Coordenador do Programa de Pós-Graduação em Direito da PUC-SP há seis anos, duas vezes reeleito. Daí, porque é para tanto essencial o desempenho pessoal do professor incumbido da coordenação dos cursos de mestrado e doutorado, a Faculdade de Direito da PUC-SP detém o melhor conceito na avaliação oficial dos programas brasileiros de pós-graduação em Direito.

Em suma, seja por seus títulos, seja mercê do brilhante concurso a que se submeteu, o professor Paulo de Barros Carvalho - que ao ser recebido entre nós passa a ser o único professor titular da USP e da PUC por concurso, em ambas as instituições, em uma mesma disciplina - o professor Doutor Paulo de Barros Carvalho, dizia, bem merece a honra conquistada.

Por tudo isso me permito, neste momento, rememorar alguns diálogos que mantivemos Geraldo Ataliba e eu. Sabíamos que, em razão de inúmeras circunstâncias, imediatamente após a aposentadoria de nosso Alcides Jorge Costa nenhum colega do Departamento de Direito Econômico-Financeiro habilitar-se-ia a sua sucessão. O nome de Paulo e a firme disposição de o estimularmos a preparar-se para o concurso surgiu naturalmente.

Por isso agora me permito também dizer, meu caro Paulo, que entre os amigos que celebram a data de hoje - mas estenderão as comemorações até amanhã, 15, dia do seu aniversário - entre os seus amigos, de modo a poder ser visto apenas de relance, encontra-se o nosso Ataliba, na lembrança que dele temos.

Há, meu caro amigo, por certo há um lugar, nutrido por nossas boas lembranças, onde se encontram os homens de boa-vontade, lá onde há de estar o 
Geraldo. Lá, desse mesmo lugar, hão de agora também deitar os olhos sobre nós os velhos Leonardo e Werner, que nos ensinaram a Amizade.

Repito agora, com a autorização de nosso amigo Hermes Marcelo Huck, o que disse ao recebê-lo, em nome da D. Congregação, em uma solenidade como a de agora.

Professor Paulo de Barros Carvalho: os nossos Maiores estendem-lhe as mãos. Vinde a nós - eles dizem (vejo-os bem: Brotero, Herculano de Freitas, Pedro Lessa, Canuto) - vinde a nós, dizem, vinde fruir essa imensa alegria de sermos da Academia do Largo de São Francisco, de fazermos parte dela, de sermos de tal modo que sem ela já não somos.

Devo dizer, contudo, que a fruição, em sua plenitude, das glórias da Faculdade somente é admitida aos que a amam e a proclamam, no quotidiano e no sempre, desde os pequenos até os mais largos gestos. Não basta a sua conquista - é necessário preservarmos o seu passado, mas também construindo o presente e o porvir.

Sendo assim, vigoroso é o desafio que enfrentamos, em especial porque a nós incumbe - e assim nós a honramos, como um cavaleiro medieval honra sua dama - a defesa do Direito e da Constituição. Os dias que vivemos são extremamente expressivos.

De uma banda os trinta anos do AI5, que de modo tão duro nos ensinou a dor da ausência de democracia e a brutalidade de certos homens, mas deixou também, a evidência - e essa deve ser lembrada a todo instante - de que não existem espectadores inocentes! Sim, professor, é imperioso repetirmos para que todos ouçam: não existem espectadores inocentes!

De outra, os dez anos dessa que é a mais bela das Constituições de nosso tempo, a Constituição que afirma a dignidade da pessoa humana e define, em seu art. $3^{\circ}$, o programa do Brasil e da sociedade brasileira:

"construir uma sociedade livre, justa e solidária; garantir o desenvolvimento nacional; erradicar a pobreza e a marginalização e reduzir as desigualdades sociais e regionais; promover o bem de todos, sem preconceitos de origem, raça, sexo, cor, idade, a quaisquer outras formas de discriminação" 
Esta é a Constituição do Brasil, nem sempre respeitada, é certo veja-se os escândalos que se sucedem e as privatizações que tornam a minha Pátria "tão pobrinha" para lembrar o Poeta - mas que sobreviverá aos tolos e aos que a ela não dão crédito, seja porque já envelheceram mais do que o devido, seja por declínio moral.

Professor doutor Paulo de Barros Carvalho:

Ainda que sendo breve, direi tudo quanto deve ser dito.

Aqui estamos, sob a luz da velha e sempre nova Academia, seja para produzir a boa reflexão jurídica, seja para prover a defesa da Constituição. Esses, os nossos dois ofícios.

Mãos à obra.

São Paulo, dezembro de 1998. 